\title{
Pemanfaatan Limbah Kotoran Sapi Menjadi Pupuk Organik Sebagai Upaya Mendukung Usaha Peternakan Sapi Potong di Kelompok Tani Ternak Mandiri Jaya Desa Moropelang Kec. Babat Kab. Lamongan
}

\author{
Sholihul Huda ${ }^{1}$, Wiwik Wikanta ${ }^{2}$ \\ FIK Universitas Muhammadiyah Surabaya \\ FKIP Universitas Muhammadiyah Surabaya
}

\begin{abstract}
ABSTRAK
Usaha peternakan sapi di Indonesia sampai saat ini masih mementingkan produktivitas ternak dan belum memaksimalkan pemanfaatan limbah kotoran sapi (teletong) bernilai ekonomis. Limbah kotoran sapi (teletong) yang dihasilkan seharusnya tidak lagi menjadi beban biaya usaha tetapi menjadi hasil ikutan yang memiliki nilai ekonomi tinggi dan bila mungkin setara dengan nilai ekonomi produk utama (daging). Tujuan penelitian ini adalah untuk mengkaji pemanfaatan kotoran sapi menjadi pupuk organik yang mendukung usaha peternakan penggemukan sapi potong. Metode yang digunakan dalam penelitian ini adalah metode deskriptif dengan metode pengumpulan data observasi dan wawancara anggota kelompok tani ternak dan didukung dengan studi literatur. Berdasarkan hasil observasi dan wawancara diperoleh hasil bahwa anggota Kelompok Tani Ternak Mandiri Jaya sudah memanfaatkan dan mengelolah limbah kotoran sapi menjadi pupuk organik yang bernilai ekonomis dengan di jual ke anggota untuk pupuk lahan pertanian padi, semangka dan belewah. Alasan penggunaan kotoran sapi sebagai pupuk biasanya karena barangnya mudah didapat, relatif murah dan memberikan hasil yang lebih baik.
\end{abstract}

Kata kunci: Kotoran ternak, sapi potong, pupuk organik, Kelompok Tani Ternak

\section{PENDAHULUAN}

Sektor peternakan di Indonesia sampai hari ini masih menjadi salah sumber ketahanan pangan yang sangat strategis. Namun kondisi di lapangan belum terkelolah secara professional tetapi sebagian besar merupakan usaha peternakan rakyat berskala kecil yang berada di perdesaan dan maish menggunakan teknologi secara sederhana atau tradisional. Menurut Nastiti (2008), usaha peternakan di Indonesia didominasi oleh usaha rakyat dengan menggunakan cara tradisional masih merupakan usaha sampingan serta lebih menjadi "tabungan" dan salah satu indikator "status sosial". Pengembangan sektor usaha peternakan sekarang ini diarahkan tidak hanya terkait dengan pemenuhan pangan (susu dan daging) namun juga mulai dikembangkan pada pemanfaatan limbah kotoran sapi (teletong) menjadi pupuk organik.

Kotoran sapi merupakan salah satu bahan potensial untuk membuat pupuk organik (Budiayanto, 2011). Kebutuhan pupuk organik akan meningkat seiring dengan permintaan akan produk organik. Menurut Prawoto (2007), hal ini disebabkan karena produk organik rasanya lebih enak, lebih sehat, dan baik bagi lingkungan. Lebih lanjut menurut Prawoto, pada tahun 1998, pangsa pasar dunia produk organik dalam 10 tahun mendatang akan mencapai sekitar US \$ 
100 milyar. Lanjutnya di Amerika Serikat, pada tahun 1997, pangsa pasar produk organik sekitar US \$ 3.5 milyar per tahun dan dalam tahun 2000 meningkat sekitar dua kali lipatnya. Menurut Prabowo (2012), dalam 10 tahun terakhir, pasar organik naik 228 persen dan nilai perdagangannya menembus 59,1 miliar. Lebih lanjut dikatakan meski tahun 2012 Eropa masih akan terimbas ekonomi namun pasar produk organik yang mengutamakan kesehatan akan terus tumbuh dan juga pasar organik di AS, Brasil, Rusia, India dan China. Ditambahkan Prabowo (2012), nilai perdagangan produk organik AS tahun 2011 mencapai 30 miliar dollar AS dan diperkirakan sampai tahun 2015 pertumbuhan ratarata pasar organik Amerika Utara sebesar 12 persen. Menurut Sulaeman (2007), pertumbuhan permintaan produk pertanian organik di seluruh dunia mencapai rata-rata $20 \%$ per tahun. Lanjutnya, data WTO menunjukkan bahwa dalam tahun 20002004 perdagangan produk pertanian organik telah mencapai nilai rata-rata 17,5 miliar dolar AS.

Satu ekor sapi setiap harinya menghasilkan kotoran berkisar $8-10 \mathrm{~kg}$ per hari atau 2,6 - 3,6 ton per tahun atau setara dengan 1,5-2 ton pupuk organik sehingga akan mengurangi penggunaan pupuk anorganik dan mempercepat proses perbaikan lahan. Potensi jumlah kotoran sapi dapat dilihat dari populasi sapi. Populasi sapi potong di Indonesia diperkirakan 10,8 juta ekor dan sapi perah 350.000 - 400.000 ekor dan apabila satu ekor sapi rata-rata setiap hari menghasilkan 7 kilogram kotoran kering maka kotoran kotoran sapi kering yang dihasilkan di Indonesia sebesar 78,4 juta kilogram kering per hari (Budiyanto, 2011). Keadan potensial inilah yang menjadi alasan perlu adanya penanganan yang benar pada kotoran ternak. Limbah peternakan yang dihasilkan tidak lagi menjadi beban biaya usaha akan tetapi menjadi hasil ikutan yang memiliki nilai ekonomi tinggi dan bila mungkin setara dengan nilai ekonomi produk utama (daging) (Sudiarto, 2008).

Dengan begitu, usaha peternakan ke depan harus dapat dibangun secara berkesinambungan sehingga dapat memberikan kontribusi pendapatan yang besar dan berkelanjutan, lanjut Sudiarto (2008). Nastiti (2008) mengatakan penerapan teknologi budidaya ternak yang ramah lingkungan dapat dilakukan melalui pemanfaatan limbah pertanian yang diperkaya nutrisinya serta pemanfaatan kotoran ternak menjadi pupuk organik dan biogas dapat meningkatkan produktivitas ternak, peternak dan perbaikan lingkungan.

Berdasarkan latarbelakang diatas maka tujuan penelitian ini adalah bagaimanakah proses pemanfaatan limbah kotoran sapi (teletong) menjadi pupuk organic dalam upaya mendukung usaha peternakan sapi potong di Kelompok Mandiri Jaya Desa Moropelang Kecamatan Babat Kabupaten Lamongan.

\section{METODE PENELITIAN}

Penelitian dilaksanakan pada bulan Juli sampai dengan September 2014 di peternak penggemukan sapi potong Kelompok Mandiri Jaya Desa Moropelang Kecamatan Babat Kabupaten Lamongan.

Penentuan lokasi dilakukan dengan pertimbangan bahwa Kelompok Tani Ternak Mandiri Jaya Desa Moropelang merupakan salah satu Kelompok Tani Ternak yang berhasil dalam program Sarjana Membangun Desa (SMD) di 
dearah Lamongan, dengan dipilih oleh Bank Indonesia (BI) untuk mendapatkan CSR bantuan pembanguan Kandang dan alat peternakan. Jumlah anggota peternak sekitar 15 orang dengan populasi sapi sekitar 30 ekor sapi. Metode yang digunakan dalam penelitian ini adalah metode deskriptif. Metode pengumpulan data yang digunakan adalah dengan metode observasi lapangan dan wawancara terstruktur atau wawancara mendalam.

Wawancara terstruktur digunakan untuk mendapatkan berbagai informasi budidaya cara pengelolaan kotoran ternak yang dilakukan peternak di di Kelompok Mandiri Jaya Desa Moropelang Kecamatan Babat Kabupaten Lamongan. Sedangkan wawancara mendalam digunakan untuk menggali lebih dalam informasi yang diperoleh mengenai pengelolaan kotoran ternak dan faktorfaktor yang mempengaruhi peternak penggemukan sapi potong memilih cara pengelolaan tersebut. Analisis yang digunakan dalam penelitian ini adalah deskriptif kualitatif. Fenomena yang ingin dilihat dalam penelitian ini adalah pengalaman peternak dalam memanfaatkan kotoran ternak sapi menjadi pupuk organik. Informan dalam penelitian adalah peternak penggemukan sapi potong di Kelompok Mandiri Jaya Desa Moropelang Kecamatan Babat Kabupaten Lamongan. Fokus penelitian adalah pemanfaat pengelolaan kotoran sapi dan faktor yang mempengaruhi peternak penggemukan sapi potong melakukan pengelolaan tersebut.

\section{HASIL DAN PEMBAHASAN Profile Kelompok Tani Ternak}

Kelompok Tani Ternak Mandiri Jaya di dirikan pada bulan Februari 2012 di Desa Moropelang Kec. Babat. Kab.
Lamongan oleh sebagian aktivis Muda Muhammadiyah dari Desa Moropelang Lamongan yaitu (Sholikh Al Huda/Sekjen Pemuda Muhammadiyah Jatim, Zudi Hariyanto/ Pemuda Muhammadiyah Cabang Babat Lamongan, Kholek Effendi dan Fastabiqul Khairat/ Pemuda Muhammadiyah Ranting Moropelang) dan diback up oleh Bapak-Bapak Muhammadiyah Ranting Moropelang Babat Lamongan.

Sejarah awal terbentuknya kelompok Tani Ternak Mandiri Jaya berawal dari kesadaran sosial para aktivis muda, pertama, melihat kemiskinan masyarakat desa karena sebgaian besar mereka sangat bergantung dengan hasil sawah yang tidak menentu karena para tengkulak yang mempermainkan harga gabah sehingga mereka sering merigu. Kedua, Banyak anak muda putus sekolah dan tidak bekerja (ngangur). Disebabkan karena peluang kerja di desa sangat terbatas dan peran steak holder desa kurang begitu memberhatikan keberdaan pemuda desa yang putus sekolah dan menggangur, sehingga sebagaian besar mereka banyak lari ke Kota dan itu berpengaruh pada perkembangan lambat karena tidak ada SDM muda dalam pembangunan desa. Dan mereka yang bertahan di desa dianggap sampah masyarakat. Ketiga, kevakuman gerakan dakwah Pemuda Muhammadiyah dengan kondisi ketidakadaan suport dana dakwah.

Berawal dari kesadaran sosial dan realitas obyektif yang terjadi di desa maka kami bertekad bangkit dengan berijtihad membentuk Kelompok Tani Ternak dengan nama Mandiri Jaya. Langkah kebangkitan pertama Kelompok Tani Ternak Mandiri Jaya adalah mengajukan program pemberdayaan dan pengelolahan ternak sapi melalui program SMD (Sarjana Membangun Desa) pada tahun 
2012 dengan mengusulkan Penggemukan Sapi Potong berbasis pengembangan limbahUrine dan Teletong sebagai Bio gas dan pupuk orgnaik, dan berhasil dengan dapat support sapi sekitar 30 ekor.

\section{Visi \& Misi Kelompok}

Visi: "Terwujudnya Kelompok Ternak Tahun 2015 yang Profesional, Mandiri, Maju, Memiliki kebersamaan tinggi yang berbasis pada Kelompok dan pengembangan Teknologi dalam rangka kesejahteraan Petani".

\section{Misi}

a. Mewujudkan pengelolahan Ternak yang Profesional, maju dan mandiri

b. Mewujudkan pengembangan pengelolahan limbah ternak yang bernilai ekonomis

c. Mewujudkan kesejahteraan perekonomian masyarakat petani

d. Mewujudkan SDM kelompok yang berkualitas di bidang ekonomi peternakan

e. Mewujudkan kelompok yang memiliki kepedulian sosial dan kebersamaan.

f. Mewujudkan kemitraan kelompok petani/ternak secara lokal dan global

\section{Target Utama}

Pembangunan Agroekobis Peterna-

kan secara integratif (Agroekobis Terpadu)

\section{Tujuan Kelompok}

a. Pembangunan kemandirian ekonomi dan kesejahteraan masyarakat petani melalui pengelolahan ternak

b. Pembangunan lapangan kerja bagi masyarakat terutama di kalangan pemuda desa melalui pengelolahan ternak c. Pembangunan sektor usaha ekonomi kecil masyarakat desa dari hasil pengelolahan ternak

\section{Prinsip Organisasi}

a. Landasan: Amanah dan Ihsan

b. Prinsip Kedudukan: Obyektif dan Independen

c. Prinsip Manajemen: Transparan, Akuntabilitas, Profesional, Efektif dan efisien, Berorientasi pada Perbaikan Terus-menerus

d. Prinsip Pengembangan: Inovatif, Kreatif, Berorientasi pada Social Entrepreneurship dan Investasi Sosial

e. Prinsip Aktivitas Inti: Bisnis Peternakan Berbasis Pemberdayaan Masyarakat

\section{Budaya Organisasi}

a. Prinsip Organisasi adalah Tolok Ukur Aktivitas Kampoeng Ternak

b. Penyelenggaraan bBisnis Peternakan Berbasis Pemberdayaan Masyarakat Secara Obyektif dan Independen;

c. Transparan, Akuntabel, Profesional, Efektif dan Efisien Serta Berorientasi pada Perbaikan Terus Menerus adalah Kegiatan Utama Kampoeng Ternak

d. Optimalisasi Penyelenggaraan Peternakan Berbasis Pemberdayaan Masyarakat adalah Orientasi Produktivitas Kampoeng Ternak

e. Amanah, Ihsan dan Profesional Adalah Inti Kualitas SDM Kampoeng Ternak

Slogan Organisasi, Tani Sejahtera Indonesia Jaya

\section{Perkembangan Kelompok}

Aset Kelompok Ternak Mandiri Jaya hingga Desember 2012 adalah:

a. Jumlah Sapi : 30 Ekor pada saat Idul Adha 2012 terjual 19 ekor sisa 10 ekor 
dan beli 4 ekor jumlah sekarang 14 ekor sapi terdiri dari 4 ekor Sapi Betina dan 10 Ekor Sapi Jantan dan 2 Ekor Pedhet

b. Tanah 1500 M2 dan bangunan Kandang, Rumah Pakan

c. Alat Mesen Chopper, Mixer Mill, Hammer Mill dan Timbangan Sapi.

d. Instalasi Biogas dan Pupuk organik

\section{Struktur Kelompok}

a. Pembina: UPT Dinas Peternakan Kec. Babat Lamongan, Kepala Desa Moropelang

b. Pengawas: PR Muhammadiyah moropelang, PR Pemuda Muhammadiyah oropelang

c. Pengurus:

$\begin{array}{ll}\text { Ketua } & : \text { Kholeq Effendi } \\ \text { Sekretaris } & : \text { Mubarok } \\ \text { Bendahara } & : \text { Zuli Soffani }\end{array}$

Bidang - Bidang

Bidang Pengembangan Jaringan \& Lembaga

Koordinator: Sholikh Al Huda

Bidang Pengembangan \& Pengelolahan Ternak

Koordinator: Tasram, Anggota: Mudhofar, Musthofa

Bidang Pengembangan Teknologi Limbah Ternak

Koordinator: Agus S, Anggota: Fastabiqul Khairat, Darmo Warsito

Bidang Pembelian \& Pemasaran

Ternak

Koordinator: Sunawi, Anggota: Kartidjan, Atrup

Bidang Pemberdayaan Ekonomi Kelompok \& Sarpras

Koordinator: Zudi Hariyanto, Anggota: Mujiadi

\section{Program Kerja Kelompok}

A. Policy Umum
1. Rapat Evaluasi Bulanan Kelompok (Minggu ke 4)

1. Laporan Keuangan Kelompok

2. Laporan Perkembangan Ternak

3. Laporan Kinerja Kelompok

2. Rapat Kondisional Kelompok

3. Rapat Koordinasi Dengan Pihak luar

B. Bidang Pengembangan Jaringan \& Lembaga

1. Studi Banding ke Peternakan Maju

2. Silaturahim ke Dinas Peternakan

3. Membuat promosi kemajuan kelompok ternak melalui internet \& Buletin Kelompok Ternak

4. Menjalin hubungan kerjasama dengan pihak luar/ perusahan pengelolah ternak

C. Bidang Pengembangan \& Pengelolahan Ternak

1. Pelatihan Pengelolahan ternak (vaksinasi, kesehatan dan peramuan makan ternak)

2. Pelatihan pengelolahan kandang ternak yang sehat

D. Bidang Pengembangan Teknologi Limbah Ternak

1. Pelatihan pengelolahan Bio Urine Ternak

2. Pelatihan pengelolahan pupuk organik dari kotoran sapi

E. Bidang Pembelian \& Pemasaran Ternak

1. Kerjasama penjualan ternak ke RPH (Rumah Potong Hewan)

2. Kerjasam penjualan dengan pengusaha sapi dan daging

F. Bidang Pemberdayaan Ekonomi Kelompok \& Sarpras

1. Pembentukan Arisan/Koperasi kelompok

2. Pengelolahan hasil ternak (daging) bernilai Ekonomis 
3. Penyedian dana sosial bagi anggota /CSR

\section{Karakteristik Peternak}

Berdasarkan hasil wawancara yang dilakukan, usaha peternakan sapi yang dilakukan oleh Kelompok Mandiri Jaya Desa Moropelang Kecamatan Babat Kabupaten Lamongan, adalah sistem penggemukan sapi potong dengan masa pemeliharaan rata-rata sekitar 7-9 bulan. Selain itu, sebagian besar anggota taniternak yang menjadi responden mempunyai pekerjaan lain sebagai petani padi.

Karakteristik anggota kelompok ternak sapi potong tersebut dapat dilihat pada tabel berikut:

Tabel 1. Karakteristik Anggota Kelompok Mandiri Jaya Desa Moropelang Kecamatan Babat Kabupaten Lamongan Berdasarkan Pekerjaan

\begin{tabular}{|c|l|c|c|}
\hline No & Pekerjaan & Jumlah & $\boldsymbol{\%}$ \\
\hline 1 & Guru & 4 & 25 \\
\hline 2 & Petani & 9 & 65 \\
\hline 3 & Pedangan & 2 & 10 \\
\hline \multicolumn{2}{|c|}{ Jumlah } & 15 & $100 \%$ \\
\hline
\end{tabular}

Tabel.2. Karakteristik Anggota Kelompok

Mandiri Jaya Desa Moropelang Kecamatan Babat Kabupaten Lamongan Berdasarkan Usia

\begin{tabular}{|c|c|c|c|}
\hline No & Usia & Jumlah & \% \\
\hline 1 & $30-35$ & 5 & 35 \\
\hline 2 & $35-40$ & 4 & 25 \\
\hline 3 & $40-50$ & 4 & 25 \\
\hline 4 & $50-60$ & 2 & 15 \\
\hline \multicolumn{2}{|c|}{ Jumlah } & 15 & $100 \%$ \\
\hline
\end{tabular}

Tabel.3. Karakteristik Anggota Kelompok Mandiri Jaya Desa Moropelang Kecamatan Babat Kabupaten Lamongan Berdasarkan Pendidikan Formal

\begin{tabular}{|c|c|c|c|}
\hline No & Pendidikan & Jumlah & \% \\
\hline 1 & SD & 5 & 35 \\
\hline 2 & SMP & 2 & 15 \\
\hline 3 & SMA & 4 & 25 \\
\hline 4 & S1 & 4 & 25 \\
\hline \multicolumn{2}{|c|}{ Jumlah } & 15 & $100 \%$ \\
\hline
\end{tabular}

Berdasarkan Tabel diatas, jumlah terbesar berdasarkan profesi pekerjaan anggota kelompok tani trenak ini adalah mayoritas petani sawah (65\%), hal ini menunjukan bahwa berternak di daerah itu masih menjadi kerjaan sampingan belum menjadi perioritas mata pencaharian. Selanjutnya junlah umur responden antara 30-35 tahun dengan persentase $35 \%$ dari total jumlah anggota. Golongan umur tersebut masih berada pada umur produktif sehingga diharapkan mampu mengembangkan usaha dan mudah memperkaya pengetahuan dan ketrampilan tentang penggemukan sapi potong dan pemanfaatan limbah kotoran sapi menjadi pupuk organik. Selanjutnya, jumlah terbesar pendidikan formal yang ditekuni peternak adalah SD (35\%). Pendidikan yang relatif rendah ini dapat menyebabkan peternak sulit menerima inovasi teknologi baru dan cenderung menggunakan cara yang biasanya dilakukan oleh pendahulunya yang masih tradisional.

Sedangkan rata-rata lama beternak sapi potong yang dilakukan oleh Kelompok Mandiri Jaya Desa Moropelang Kecamatan Babat Kabupaten Lamongan sekitar \pm 3 tahun. Proses beternak yang bisa dikatakan masih baru ini salah satu kendala yang dihadapi adalah kemampuan memecahkan bebagai permaslahan yang dihadapi dalam peneglolahan usaha peternakan dan kemampuan mengadopsi inovasi teknologi peternakan sapid an pemanfaatan limbah kotoroan sapi.

\section{Pemanfaatan Kotoran Sapi}

Menurut Nastiti (2008), pupuk organik dapat memperbaiki kualitas dan kesuburan tanah serta diperlukan tanaman. Selain itu, kotoran ternak yang diubah menjadi biogas dapat membantu 
mengatasi kesulitan dan kemahalan bahan bakar minyak yang banyak digunakan oleh masyarakat terutama di pedesaan. Hasil observasi dan wawancara menunjukkan bahwa sebagian besar anggota tani ternak telah memanfaatkan kotoran sapi untuk kebutuhan sendiri sebagai pupuk pertanian padi dan semangka. Sebagian besar anggota tani ternak memberikan alasan yang relatif hampir sama tentang penggunaan kotoran sapi sebagai pupuk yaitu biasanya karena barangnya mudah didapat, relatif murah dan memberikan hasil yang lebih baik.

Berdasarkan pengamatan menunjukan bahwa pemanfatan kotoron sapi menjadi pupuk, masih terbatas kapasitasnya dan peruntukannya, terbatas pada kebutuhan anggota kelompok tani ternak yang mayoritas adalah petani sawah. Proses pembuatan pupuk organic dari kotoran sapi di Kelompok Mandiri Jaya Desa Moropelang Kecamatan Babat Kabupaten Lamongan sudah menggunakan instalasi biogas sebagai alat produksi pembuatan pupuk organik. Berdasarkan wawancara anggota kelompok tani ternak, instalasi biogas ini lebih di manfaatkan untuk memproduksi pupuk dari pada biogas, karena menurutnya yang paling dibutuhkan warga adalah pupuk organic untuk pertanian daripada biogas karena sebagai besar mereka masih suka memggunakan gas Elpiji dengan alasan praktis. Proses pembuatan pupuk organic kotoran sapi adalah sebagai berikut:

Alat dan Bahan Peralatan yang diperlukan antara lain: instalasi biogas, bak (kotak kayu ukuran 1x1x1 m) 3 buah, sekop, ember, ayakan, termometer, karung/kampil, timbangan, kantong plastik, dan lain-lain.

Bahan yang diperlukan: kotoran ternak 1 ton (+ 30 karung), urea $2 \mathrm{~kg}$, SP-
$363 \mathrm{~kg}$, kapur $5 \mathrm{~kg}$, starter trichoderma 3 $\mathrm{kg}$ atau EM4, plastik hitam $5 \mathrm{~m}$.

Cara Pembuatan:

a. Siapkan kotoran ternak (sapi atau kerbau) yang akan dijadikan kompos dengan syarat kering (tidak basah oleh urine sapi atau air hujan). Kotoran ternak yang terlalu basah akan mempengaruhi berkembangnya cendawan Trichoderma harzianum sehingga proses perombakan lebih lambat.

b. Bahan aktivator (Urea, SP-36, kapur, pupuk kandang, starter Trichoderma harzianum) diaduk merata dan dibagi atas 4 bagian.

c. Kotoran ternak ditumpuk setinggi 1x1x1 m lalu dibagi atas 4 bagian, masing-masing setinggi $+25 \mathrm{~cm}$.

d. Di atas tumpukan kotoran ternak, ditabur bahan aktivator secara merta sebanyak $1 / 4$ bagian.

e. Gabung tumpukan kotoran ternak menjadi 1 tumpukan sehingga volume tumpukan $1 \mathrm{x} 1 \mathrm{x} 1 \mathrm{~m}$.

f. Tutup tumpukan dengan plastik hitam anti air agar terlindung dari hujan dan panas matahari.

g. Lakukan pembalikan tumpukan kotoran ternak setiap 1 minggu dengan menggunakan cangkul. Perlu dijaga, kelembaban tumpukan harus stabil (kelembaban 60-80\%) selama proses pengomposan.

h. Panen kompos pupuk kandang dapat dilakukan setelah 21 hari dengan cara membongkar lalu diayak sehingga dihasilkan kompos yang sempurna.

\section{Aspek Ekonomi}

Pemanfaatan limbah kotoran sapi yang dikelolah menjadi pupuk organic pada aspek ekonomi tentu sangat bermanfaat bagi penambahan pendapatan petani ternak sehinggi dapat membantu 
memenuhi kebutuhan ekonominya sehingga harapan terbesar dari proses ini adalah petani ternak sejahtera dan mandiri secara ekonomi. Hasil dari wawancara dengan anggota Kelompok Tani Ternak Mandiri Jaya Desa Moropelang Kecamatan Babat Kabupaten Lamongan didapatkan analisa usaha dari pemanfaatn limbah kotoran sapi menjadi pupuk organic sangat potensial baik pendapatan maupun pasarnya. Hal itu di sebabkan bahan baku yang tersedia (teletong) tidak beli dan proses pembuatannya tidak membutuhkan bahan yang mahal sehingga menekan biaya produksi, sementara pangsa pasar potensial dikarenakan sebagian basar petani mulai beralih menggunakan pupuk organic karena selain lebih murah juga muda di dapatkan dari pada pupuk kimia harga mahal sulit didapat.

Dari pemaparan anggota kelompok didapati analisa usaha sebagia berikut, bahwa kotoran sapi tersebut dapat dimanfaatkan menjadi dua macam pupuk, yaitu pupuk organic padat dan pupuk organik cair.

Untuk analisa usaha pupuk organic padat adalah:

A. Biaya Produksi:

1. Bahan baku teletong Rp. $500 / \mathrm{kg}$ sekali produksi $1000 \mathrm{~kg}$ (1ton) $\mathrm{x}$ $500=500.000$

2. Bahan pengurai organisme (EM-4, Urea, $\quad$ Tebu, dll) Rp.100.000/produksi

3. Alat produksi (Bak, Cangkul, Karung dll), Rp. 50.000

4. Tenaga Kerja, Rp. 200.000/ produksi

Total Biaya Produksi $=$ Rp. 750.000/produksi

B. Penjualan

$1 \mathrm{Kg}$ Pupuk organic padat harga= Rp.1000
Hasil produksi 1 ton Pupuk organic padat $(1000 \mathrm{~kg}$ (1ton) x Rp.1000= Rp.1.000.000

Keuntungan $=$ Penjualan - Biaya Produksi Rp.1.000-Rp.750.000= Rp.250.000/

Produksi Dalam 1 bulan dapat memproduksi 2 kali berarti dapat dihitung perbulan kelompok tani ternak mendapatkan keuntangan Rp.1000.000 x 2 kali produksi/bulan $=\mathrm{Rp} .2 .000 .000 / \mathrm{bln}$.

Untuk analisa usaha pupuk organic cair adalah:

A. Biaya Produksi

1. Bahan baku teletong $1 \mathrm{~kg}=\mathrm{Rp}$. $500,-\mathrm{x} 1000 \mathrm{~kg}=\mathrm{Rp} .500 .000$

2. Bahan pengurai organism $=$ Rp.200.000

3. Alat produksi $=$ Rp. 250.000

4. Tenaga Kerja $=$ Rp.300.000/Produksi

Total Biaya Prduksi =R.1.250.000

B. Penjualan

Harga pupuk organic cair per 1 ltr $=\mathrm{Rp}$. 2.500

Dalam sekali produksi menghasilkan \pm 800 liter $x \quad$ Rp. $\quad 3.000=$ Rp.2.400.000/produksi

Jadi per produksi menghasilkan keuntungan sebgai berikut $=$ Hasil penjualan-biaya produksi Rp.2.400.000-1.250.000=

Rp.1150.000/produksi x 2 kali produksi per bulan $=$ Rp. $2.300 .000 /$ bulan.

Dari perhitungan analisa usaha di atas menunjukan bahwa pemanfatan limbah kotoran sapi (teletong) yang dijadikan pupuk organic baik padat ataupun cair ternyata dapat mengahsilkan pendapatan keuntungan ekonomi yang lumayan besar bagi petani ternak. Sehingga sedikit banyak dapat membantu meningkatkan pendapatan ekonomi dan 
membantu peningkatan kesejahteran hidup petani. Selain itu dapat juga membantu peningkatan produksi pertanian yang berbasis pupuk organic yang sangat menunjang bagi kesehatan masyarakat.

\section{Aspek Lingkungan}

Limbah kotorona sapi (teletong dan urine) kalau tidak diolah atau di daur ulang akan berpotensi menganggu dan mencemari lingkungan. Menurut Martinez dkk (2009), kotoran ternak dapat menghasilkan $\mathrm{NH} 3$ yang apabila bersatu dengan debu dalam jangka waktu lama akan menyebabkan beberapa penyakit yang terkait dengan paru-paru dan pada konsentrasi tinggi akan menurunkan daya tahan ternak.

Oleh karena itu dengan pemanfaatan limbah kotoran ternak (teletong) menjadi pupuk organic padat dan cair tentu akan sangat membantu untuk menjaga kesehatan lingkungan dan keshatan masyarakat sekitar peternakan. Sehingga, di satu sisi peternak dapat mengelolah usaha penggemukan sapi potong dengan pemanfatan limbah kotoran secara nyaman dan tenang karena tidak menggangu masyarakat, dan di satu sisi masyarakat (petani) dapat memanfaatkan hasil olahan limbah ternak menjadi pupuk organic bagi kebutuhan produksi pertaniannya, sehingga terjalin hububungan simbiosi mutualisme antara peternak dengan masyarakat sekitar.

\section{SIMPULAN}

Hasil observasi dan wawancara dengan anggota Kelompok Tani Ternak Mandiri Jaya di Desa Moropelang Babat Lamongan, menunjukkan bahwa anggota Kelompok Tani ternakk telah memanfaatkan kotoran sapi (teletong) menjadi pupuk organic padat dan cair walaupun masih dengan kapasitas terbatas bagi kebutuhan anggota dan masyarakat sekitar peternakan.

Dari hasil pemanfaatan limbah kotoran sapi menjadi pupuk organic ternyata menghasilkan potensi ekonomi yang lumayan besar bagi anggota kelompok tani ternak sehingga dapat meningkatkan pendapatan ekonomi, sehingga dapat mendorong kesejahertaan petani. Selain itu, pemanfaatan limbah kotoran sapi (teletong) menjadi pupuk organic juga dapat menjaga kesehatan lingkungan dan menjaga kesehatan masyarakat sekitar peternakan, karena limbah kotoron sapi ini dapat menghasilkan NH3 yang apabila bersatu dengan debu dalam jangka waktu lama akan menyebabkan beberapa penyakit yang terkait dengan paru-paru dan mencemari udara di sekitar masyarakat karena baunya. Sehingga dengan pemanfaatn limbah tersebut dapat membangun hubungan yang simbiosis muatualisme yang saling memanfaatkan secara positif.

\section{DAFTAR PUSTAKA}

Budiyanto, Krisno. 2011. "Tipologi Pendayagunaan Kotoran Sapi dalam Upaya Mendukung Pertanian Organik di Desa Sumbersari Kecamatan Poncokusumo Kabupaten Malang. Jurnal GAMMA 7 (1) $42-49$

Martinez dan Jose, Patrick Dabert, Suzelle Barirngton, dan Colin Burton. 2009. "L:ivestock Waste Treatment Systems for Enviromental Quality, Food Safety and Sutainability."Jurnal Science Direct Bioresource Technology 100 (2009) $5527-5536$

Melse, Roland dan Maikel Timmerman. 2009. "Sustainable Intensive 
Sholihul Huda ${ }^{1}$, Wiwik Wikanta ${ }^{2}$ /Aksiologiya: Jurnal Pengabdian Kepada Masyarakat. Vol.1, No.1, Februari 2017 Hal 26 - 35

Livestock Production Demands Manure and Exhaust Air Treatment Technologies.” Jurnal Science Direct Bioresource Technology 100 (2009) $5506-5511$

Nastiti, Sri. 2008. "Penampilan Budidaya

Ternak Ruminansia di Pedesaan Melalui Teknologi Ramah Lingkungan." Seminar Nasional Teknologi Peternakan dan Veteriner 2008

Prabowo, Hermas. 2012. "Pasar Organik

Dunia Tumbuh Pesat."

http://health.kompas.com/.Diakses

pada tanggal 22Agustus 2013

Prawoto, Agung. 2007. "Produk Pangan

Organik : Potensi yang Blum

Tergarap Optimal." http://mbriofood.com/.Diakses pada tanggal 22 Agustus 2013

Rahayu, Sugi, Dyah Purwaningsih dan

Pujianto. 2009. "Pemanfaatan

Kotoran Ternak Sapi Sebagai

Sumber Energi Alternatif

Ramah Lingkungan beserta

Aspek Sosio Kulturalnya". Jurnal Inotek Volume 13 No. 2.
Sarwanto, Doso. 2004. "Model Pencemaran Limbah Peternakan Sapi Perah Rakyat pada Beberapa Kondisi Fiik Alami dan Sosial Ekonomi (Studi Kasus di Propinsi JawaTengah)". Disertasi Sekolah Pascasarjana Institut Pertanian Bogor

Sudiarto, Bambang. 2008. "Pengelolaan Limbah Peternakan Terpadu dan Agribisnis yang Berwawasan Lingkungan". Seminar Nasional Teknologi Peternakan dan Veteriner. Universitas Padjajaran Bandung

Sulaeman, Ahmad. 2007. "Prospek Pasar dan Kiat Pemasaran Produk Pangan Organik".Simposium Produk Pertanian Organik di Indonesia dari Produsen hingga Pemasaran ISSAAS Indonesian Chapter 4 Desember 2007 